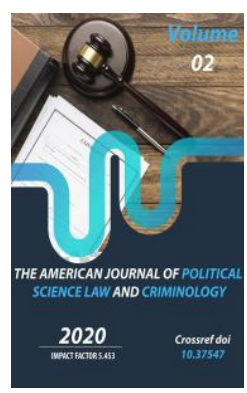

\title{
Issues Of Improving The Work Of The Labour Disputes Commission
}

\author{
Rahimkulova Lola Ulugmurodovna \\ Tashkent State Law University, Tashkent, Uzbekistan
}

Copyright: Original

content from this work may be used under the terms of the creative commons attributes 4.0 licence.

\section{ABSTRACT}

This article covers: the concepts of labour conflicts and disputes; some shortcomings in the organizational and legal form as well as activities of the Labour Disputes Commission; procedural aspects of dispute resolution in the Labour Disputes Commission; proposals and recommendations for legislation to improve the work of the Labour Disputes Commission.

\section{KEYWORDS}

Conflict, dispute, Labour Disputes Commission, intermediary, mediator, lawyer.

\section{INTRODUCTION}

One of the primary features of a democratic state and society is that the rights of citizens are fully guaranteed in practice and provided with the necessary means for effective protection.
Modern trends in the development of society in the XXI century place emphasis on the emerging relations in the field of labour. Therefore, the emergence of disagreements over the use of labour, the establishment or modification of new working conditions is the 
natural process between employers and employees. [1]

Indeed, O.A.Vinogradova acknowledges that "in a capitalist society, disagreements in labour relations are one of the inevitable phenomena of the process of organizing, applying or changing the labour in the capitalist system" [2 ].

From the philosophical point of view, labour disputes represent the unity of objective events and contradictions in the life of society, as well as the dynamics of the struggle process. As long as there is production process and the social relations associated with it, it is inevitable that there will be contradictions within it. The existence of contradictions is an objective condition of development.

According to our view, in the process of socioeconomic development of countries, as a result of incompatibility of people's thoughts and worldviews in labour relations, there are compromises, and conflicts in enterprises, organizations and institutions can never be avoided. Therefore, one of the primary aims of labour legislation is to implement effective, short-term dispute resolution measures. Of course, special emphasis will be placed on the work of the Labour Disputes Commission. One of the urgent issues facing our government is to radically improve the work of the Commission and to develop measures to simplify the process of resolving labour disputes.

In the state program on the implementation of the Strategy of Action on five priority directions of development of the Republic of Uzbekistan for 2017-2021 years in the "Year of Development of Science, Education and Digital Economy", it is envisaged to introduce the procedure for pre-trial settlement of certain categories of civil disputes, that is, labour disputes were initially considered in Labour Disputes Commission. [3]

According to Jonathan Marc Hamberger, a scientist at Macquarie University in Australia, "conflict" is a broader concept than "dispute" and can be either overt or covert in an enterprise. It is manifested by the informal expression of one or more employees' dissatisfaction against the decisions of the governing bodies of the enterprise by secretly resisting or refusing to comply with those decisions. The "dispute" will, of course, be officially warned, according to the process. Conflict manifests itself in various forms. For example, strikes, bans and restrictions, in the form of lockouts, and one of the more striking examples are conflicts that occurred in the workplace. Other types of disputes are noteworthy when they often involve making special demands or formally filing a complaint to the management. In any case, the Australian legal system pays special attention to labour disputes and seeks to study it in depth. This is because it is profoundly important to quickly resolve conflicts within the enterprise in order to keep the internal environment of the enterprise stable. [4]

The resolving of disputes arising from labour relations in the Republic of Uzbekistan by the Labour Disputes Commission reflects many positive aspects for the parties. According to the opinion of the judges: H. Yodgorov, G. Ziganshina and Sh. Axatova, resolving labour disputes by a court is often not considered the most acceptable means of resolving the conflict for the parties, instead, it will bring additional court fees. As a result, a warm relationship between employer and employee 
will be broken, and also will lead to the unintended disclosure of disputable cases. For these reasons, the settlement of labour disputes in the order of reconciliation is an urgent topic. [5]

It should be noted that the activity of the Labour Disputes Commission does not emerge in other areas of law and is unique to labour law. The resolution of disputes between the parties without the involvement of third parties is not common in other areas of law. In recent years, much attention has been paid at the government level to improve the activities of the Labour Disputes Commission.
The legislation of the Republic of Uzbekistan authorizes special bodies working in this area to consider and resolve labour disputes that cannot be resolved through peaceful negotiations between the employee and the employer.

The organizational and legal form as well as activity criteria of the Labour Disputes Commission are regulated by the relevant provisions of the Labour Code of the Republic of Uzbekistan. Article 260 of the current Labour Code provides a list of competent authorities for resolving individual labour disputes. According to this Code, labour matters can be reviewed by the following bodies:

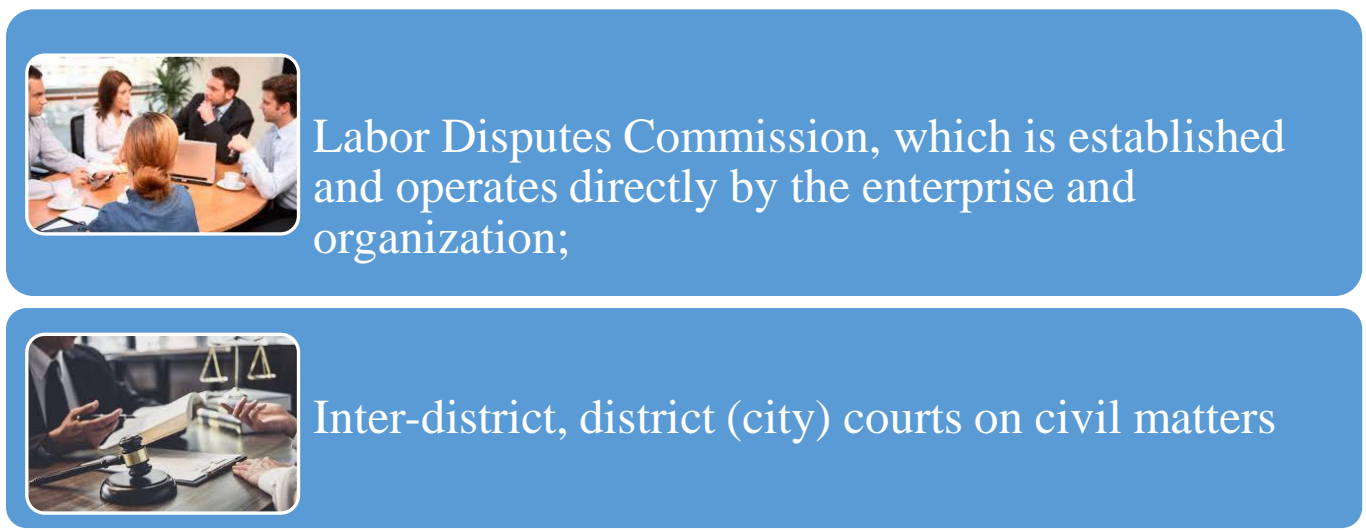

The norms of labour legislation also include the concept of certain categories of civil servants and labour disputes related to them. The labour legislation provides for specific rules and regulations for the review and resolution of labour disputes with employees belonging to certain categories of civil servants in the matters listed in the table below: 


\section{- termination of the labour contract;}

- Transfer to another job;

- Disputes over disciplinary action;

- Compensation for damages caused by the termination of an labor relationship;

Article 264 of the current Labour Code of the Republic of Uzbekistan provides for the procedure for consideration of labour disputes directly by the commission. [6] The Labour Disputes Commission is governed based on a written application submitted by an employee interested in hearing a labour dispute.

According to M.Rakhimov, the positive aspect of the Labour Disputes Commission is the simplicity of the procedure for applying to it and the short term for consideration of individual labour disputes. Moreover, this form of protection is cost-effective for both parties, and in most cases where a dispute is considered, the employee is not separated from his or her work. Even if the commission does not resolve the dispute in favour of the employee, there will be no loss to the employee. [7]

In some cases, the Commission may also refuse to accept an employee's application for a labour dispute. The following legal facts causes to refuse the application:

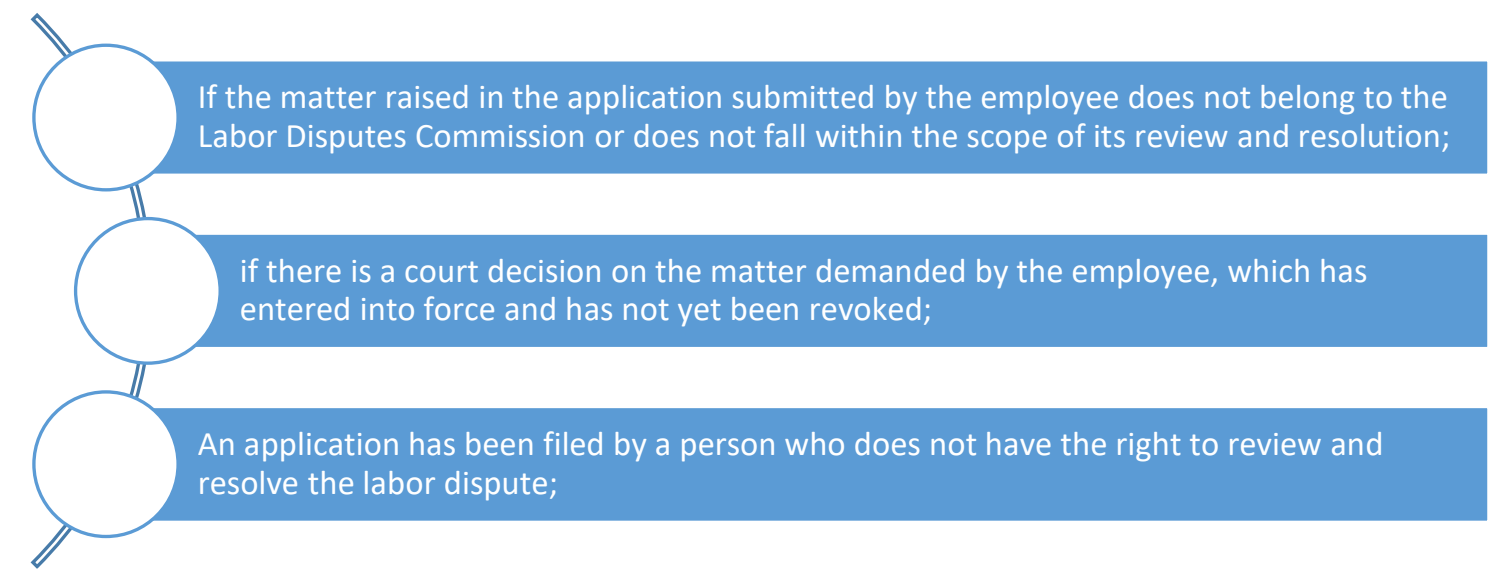

The address of the Commission should be announced to all employees and its working process should be organised conviniently. It should be noted that according to the labour legislation of the Republic of Uzbekistan, the missed deadline for an employee to apply to the Labour Disputes Commission is not a ground for refusal to accept an application for a dispute. However, at the first meeting of the Commission, the reasons for the delay by the claimant must be clarified. 
At the meeting of the Labour Disputes Commission, the employee has the right to involve lawyers or witnesses to express his interests or to clarify the situation accordingly. It is also enshrined in law that a Trade Union Committee or other representative bodies of the employee has the same power as a member of the Labour Collective and for the effective protection of the rights and interests of its members. [7]

Russian scientist A. Shepeleva admits that a wise employer, as a representative of the Labour Disputes Commission, attracts qualified lawyers who can come to the right solutions to difficult situations. In such events, the employer's representatives will never vote to the detriment of the other party in the dispute, namely the employee, to prevent him from working against himself if the matter is to be heard in court in the future. [8]

We think that this idea can also be supported. Indeed, an employee of the legal service of the enterprise or organization is an official authorized to ensure labour discipline in the territory of the enterprise, as well as the observance of labour rights.

We know that the Labour Disputes Commission is a body of special labour jurisdiction that deals with labour disputes within an enterprise or organization and can be established in any enterprise. Whether or not to set up this Commission is the right of employer and Collective of employee labour of every business entity. The labour legislation refers to the will of the employer whether or not to establish a Labour Disputes Commission through this norm since the final decision in the activities of the enterprise is rendered by the employer.
Furthermore, we believe that the following shortcomings related to the work of the Labour Disputes Commission should be addressed:

First, the procedure for establishing or not establishing a Labour Dispute Commission in enterprises, organizations and institutions depends on the full scope of the employer's authority;

Second, the norms of labour law do not clearly strengthen the scope of authority of Commission members to consider disputes. This, in many cases, violates the substantive and procedural rights of the parties to the dispute and, as a result, leads to wrong decisions and violations.

Third, thenorms of labour law do not exactly specify what types of disputes should be resolved by the Labour Disputes Commission. This leads the disputing parties to hesitation regarding the file a claim to the Commission.

Fourth, the labour legislation does not specify which specialists should be included in the Commission. In practice, this has been leading to unfair decisions made partially by the Commission.

Fifth, although Article 261 of the Labour Code stipulates that the procedure for resolving individual labour disputes is regulated by the Code, unfortunately, today in our enterprises there is no specific approved standard form for consideration of labour disputes.

Sixth, although the Commission is formed proportionally between the employer and employee representatives, in the end in most cases the dispute is not resolved impartially, and as a consequence, there is no other way for the employee, but apply to the courts; 
To conclude, the procedure for resolving labour disputes by the Commission, the organizational and legal activities of the Commission should be radically reconsidered. It is no secret that the institute of labour disputes in labour law is totally different from other institutions of labour law in its procedural nature. Therefore, so as to improve labour legislation, we propose the following:

- First, to improve the norms related to the activities of the Labour Disputes Commission in the Labour Code at the level of modern requirements;

- Second, it would be expedient to develop a regulation or instruction that would reflect the procedure that does not contradict the labour legislation and does not affect the rights of employees, as well as regulate this area.

- Third, the review and resolution of labour disputes should be regulated by a separate law. In addition, the law should specify: the powers and responsibilities of the Commission on labour disputes; procedural terms for resolving disputes in the Commission; the legal status of members of the Commission; the mandatory enforcement of the commission's decision.

- Fourth, the second part of this law should clarify the procedure for using alternative methods in resolving both types of labour disputes (individual and collective). In this case, the legislation should provide for all forms of alternative dispute resolution: including the procedure for resolving labour disputes through mutual negotiations; with the help of intermediaries and mediators, as well as matters arising by labour arbitration, should be regulated by an in-depth study of the legislation of developed countries.

\section{REFERENCES}

1. Y.Tursunov, Sh.Gaziev. Labour disputes and legal problems of their solution.T :: 2009.

2. https://cyberleninka.ru/article/n/problemy -terminologii-individualnogo-trudovogospora-istoriko-pravovoy-aspekt

3. https://lex.uz/docs/4751561

4. J. M. Hamberger . Workplace Dispute Resolution Procedures in Australia.

Chrome extension://ohfgljdgelakfkefopgklcohade gdpjf/file:///C:/Users/User/Downloads/01w hole\%20(3).pdf

5. H.Yodgorov, G.Ziganshina, Sh.Akhatova. Disputes arising from labour legal relations. T: "Bakria press" -2017

6. https://lex.uz/docs/142859

7. M.Raximov. Protection of labour rights of employees (comparative legal analysis) Monograph.T .: 2020

8. Shepelova A.A, The main directions of the effectiveness of the extrajudicial protection of labour rights and legitimate interests or questions about the need for the functioning of a Labour Dispute Commission. Page 12. 